\title{
Gambaran Faktor-Faktor yang Terkait dengan Kejadian Carpal Tunnel Syndrome pada Ibu Rumah Tangga di Desa Guji Baru
}

\author{
Mariska Nada Debora ${ }^{1}$, Suparto $^{2}$, Irvan Tanpomas ${ }^{2}$ \\ ${ }^{1}$ Mahasiswa Fakultas Kedokteran Universitas Kristen Krida Wacana \\ ${ }^{2}$ Staf Pengajar Bagian Anestesiologi, Fakultas Kedokteran Universitas Kristen Krida Wacana \\ Alamat Korespondensi : Mariska.2014fk139@civitas.ukrida.ac.id
}

\begin{abstract}
Abstrak
Carpal Tunnel Syndrome (CTS) adalah sindrom akibat penekanan nervus medianus di dalam terowongan karpal di pergelangan tangan. Komplikasi jangka panjang dari CTS meliputi penurunan fungsi tangan, kerusakan saraf dan otot, rasa sakit, cacat, kelemahan dan hilangnya sensibilitas yang persisten di daerah distribusi nervus medianus. Tujuan penelitian adalah untuk mengetahui faktorfaktor yang mempengaruhi kejadian CTS pada ibu rumah tangga yang mencuci pakaian menggunakan tangan di desa Guji Baru. Penelitian ini menggunakan penelitian deskriptif dengan teknik pengambilan sampel adalah purposive sampling. Sampel dalam penelitian ini ada 100 orang. Sebanyak 33 orang (33\%) menderita CTS. Kelompok usia dengan persentase tertinggi yang mengalami CTS adalah usia 40-45 tahun yaitu 10 orang (30\%). Lama kerja dengan persentase penderita CTS tertinggi $1 \frac{1}{2}$ jam -1 jam yaitu sebanyak 29 orang $(88 \%)$. Obesitas ditemukan pada 20 orang $(60 \%)$. Diabetes ditemukan pada 3 orang $(9 \%)$. CTS dikeluhkan pada saat hamil oleh 7 orang (21\%). Semua responden mencuci pakaian dengan posisi janggal (100\%). Dari 100 orang, 33 orang menderita CTS.
\end{abstract}

Kata kunci: sindrom terowongan karpal, ibu rumah tangga, mencuci pakaian, posisi pergelangan tangan

\section{Carpal Tunnel Syndrome Related Factors among Housewives from Guji Baru Village}

\begin{abstract}
Carpal Tunnel Syndrome (CTS) is a syndrome due to suppression of the median nerve in the carpal tunnel in the wrist. Long-term complications of CTS include decreased hand function, nerve and muscle damage, pain, defects, weakness and persistent loss of sensibilities in the median nerve distribution area. The purpose of this study was to determine the factors that influence the incidence of CTS in housewives who wash clothes by hand in Guji Baru village. The study method was descriptive with purposive sampling. The sample in this study was 100 people. From 100 respondents, $33(33.0 \%)$ of them suffered from CTS. The age with the highest percentage of CTS was 40-45 years old which were 10 persons (30\%), Obesity was found in 20 people (60\%) who suffer from CTS. Obesity was found in 20 people (60\%) who suffer from CTS. Diabetes was found in 3 people $(9 \%)$. CTS was found in pregnancy of 7 people (21\%). All respondents washed clothes with an awkward position (100\%).
\end{abstract}

Keywords: carpal tunnel syndrome, housewives, washing clothes, wrist position 


\section{Pendahuluan}

Gangguan kesehatan pada pekerja dapat disebabkan oleh faktor yang berhubungan dengan pekerjaan maupun yang tidak berhubungan dengan pekerjaan. Status kesehatan masyarakat pekerja dipengaruhi tidak hanya oleh bahaya kesehatan di tempat kerja dan lingkungan kerja tetapi juga oleh faktor pelayanan kesehatan kerja, perilaku kerja serta faktor lainnya. ${ }^{1}$

Penerapan keselamatan dan kesehatan kerja (K3) di Indonesia diatur dalam UU No.1 tahun 1970, Peraturan Menteri Tenaga Kerja Nomor: Per 05/MEN/1996 tanggal 12 Desember 1996 serta Keputusan Presiden Indonesia Nomor 22 Tahun 1993 tentang penyakit yang timbul karena hubungan kerja termasuk Carpal Tunel Syndrome. ${ }^{2}$

Carpal Tunnel Syndrome (CTS) timbul akibat penekanan nervus medianus di dalam Carpal tunnel (terowongan karpal) di pergelangan tangan dengan gejala nyeri, kebas dan kesemutan pada jari-jari (ibu jari, jari telunjuk dan jari tengah) dan tangan di daerah persarafan nervus medianus. CTS jika tidak segera dideteksi dan diobati dapat menyebabkan komplikasi jangka panjang meliputi penurunan fungsi tangan, kerusakan saraf, kerusakan otot, rasa sakit, cacat, kelemahan dan hilangnya sensibilitas yang persisten di daerah distribusi nervus medianus. ${ }^{2-4}$

Berdasarkan laporan American Academy of Orthopaedic Surgeons tahun 2007, kejadian CTS di Amerika Serikat diperkirakan satu sampai tiga kasus per 1.000 subjek pertahun. Prevalensinya berkisar sekitar 50 kasus per 1000 subjek pada populasi umum. National Health Interview Study (NHIS) memperkirakan prevalensi CTS 1,55\%. Penelitian pada pekerjaan dengan risiko tinggi di pergelangan tangan dan tangan mendapatkan prevalensi CTS antara 5,6\% sampai $14,8 \%{ }^{5}$

Prevalensi CTS lebih banyak pada populasi khusus yang berhubungan dengan pekerjaan yang menggunakan tangan, penelitian yang dilakukan di salah satu Institusi Rumah Sakit di Semarang pada tahun 2006 terdapat 34 pasien baru terdiagnosis CTS atau sekitar 4\% dari 838 pasien baru dan karakteristik pekerjaan pada penderita CTS berdasarkan pekerjaan terbanyak adalah ibu rumah tangga yaitu 21 orang $(61,8 \%)$ dengan kegiatan salah satunya mencuci. ${ }^{6}$

Pekerjaan mencuci pakaian dengan menggunakan tangan berpotensi munculnya kejadian CTS. Berkaitan dengan komplikasi yang dapat ditimbulkan dari CTS, yaitu dapat menyebabkan penurunan kualitas hidup seseorang dalam menjalani aktivitas seharihari, maka peneliti tertarik untuk meneliti faktor-faktor yang mempengaruhi kejadian CTS pada ibu rumah tangga yang mencuci pakaian menggunakan tangan di desa Guji Baru, alasan dipilihnya desa Guji Baru sebagai tempat penelitian karena belum pernah dilakukan penelitian CTS di desa Guji Baru dan setelah dilakukan observasi masih banyak ibu rumah tangga yang mencuci pakaian menggunakan tangan di desa tersebut, selain itu desa Guji Baru adalah lingkungan yang terdekat dengan Fakultas Kedokteran UKRIDA. Diharapkan dengan dilakukannya penelitian ini dapat menjadi sumber informasi sebagai data pembanding atau dasar perkembangan bagi peneliti lain khususnya tentang CTS pada ibu rumah tangga yang mencuci pakaian menggunakan tangan dan dapat membawa manfaat bagi responden melalui perantara tenaga medis sebagai sarana untuk mendeteksi dini penyakit CTS pada ibu rumah tangga yang mencuci pakaian menggunakan tangan di desa Guji Baru.

\section{Tujuan Penelitian}

Mengetahui gambaran kejadian CTS dan faktor-faktor terkait CTS, meliputi faktor usia, lama kerja, posisi pergelangan tangan, obesitas, usia kehamilan dan penyakit diabetes melitus pada ibu rumah tangga yang mencuci pakaian menggunakan tangan dengan di desa Guji Baru.

\section{Metode Penelitian}

\section{Subjek Penelitian}

Penelitian ini menggunakan desain deskriptif cross sectional dengan teknik pengambilan sampel secara purposive sampling dengan sampel sebanyak 100 orang. Penelitian ini dilakukan di desa Guji Baru Jakarta Barat pada bulan Desember 2017 sampai Januari 2018. Populasi yang diteliti adalah ibu rumah tangga. Kriteria inklusi adalah ibu rumah tangga yang mencuci 
pakaian menggunakan tangan, berusia 40 sampai 60 tahun dan bersedia menjadi sampel penelitian. Kriteria eksklusi adalah terdapat penyakit reumatik/ fraktur/ trauma.

\section{Prosedur Penelitian}

Penelitian ini telah mendapatkan persetujuan kaji etik dalam suratnya no 373/SLKE-IM/UKKW/FK/KE/XI/2017

Prosedur yang dilakukan pada penelitian adalah menjelaskan kepada pasien tujuan dan cara kerja penelitian, meminta persetujuan secara lisan kepada subjek untuk dijadikan sampel penelitian, Instrumen dalam penelitian ini menggunakan kuesioner yang berisi identitas pasien seperti usia, lama kerja saat mencuci pakaian, berat badan, tinggi badan, riwayat diabetes melitus, usia kehamilan saat mengalami keluhan CTS, kuesioner Carpal Tunnel Syndrome Scoring oleh Kamath dan Stothard, observasi posisi pergelangan tangan saat mencuci pakaian dan melakukan pemeriksaan fisik dengan tes provokasi yaitu Tes Phalen, dan mencatat hasil untuk selanjutnya diolah menjadi data penelitian.

\section{Hasil Penelitian}

\section{Gambaran Kejadian CTS}

Berdasarkan tabel 1, didapatkan bahwa responden yang menderita CTS sebanyak 33 orang $(33,0 \%)$.

Tabel 1. Gambaran Kejadian CTS

\begin{tabular}{ccccc}
\hline $\begin{array}{c}\text { Keluhan } \\
\text { Subjektif } \\
\text { CTS }\end{array}$ & \multicolumn{2}{c}{ Jumlah (orang) } & Total & $\begin{array}{c}\text { Persentase } \\
\text { (\%) }\end{array}$ \\
& \multicolumn{2}{c}{ Tes Phalen } & & \\
\cline { 2 - 3 } & Negatif & Positif & & \\
\hline $\begin{array}{c}\text { Berisiko } \\
\text { Tidak }\end{array}$ & 14 & 33 & 47 & 47,0 \\
berisiko & 53 & 0 & 53 & 53,0 \\
\hline Total & 67 & 33 & 100 & 100 \\
\hline
\end{tabular}

\section{Gambaran Usia terhadap CTS}

Berdasarkan tabel 2, usia responden yang mengalami CTS bervariasi dari usia 40 sampai 60 tahun, dimana dari kategori yang dijabarkan dari masing-masing usia, jumlah yang mengalami CTS tidak berbeda jauh. Berdasarkan penelitian yang dilakukan oleh
Firsan Ilyas (2015), bahwa usia yang sering mengalami CTS adalah usia diatas 42 tahun. Selain itu juga penelitian yang dilakukan oleh Praja Gendo (2006), didapatkan hasil bahwa usia diatas 40 tahun berisiko 9,6 kali terkena gejala CTS. Berdasarkan teori yang dikemukakan oleh Fuller kejadian CTS ditemukan semakin meningkat seiring dengan bertambahnya usia, dengan kelompok usia 40 tahun atau lebih memiliki insiden yang tinggi secara signifikan. CTS muncul dalam jangka waktu yang lama yang terjadi pada umur pertengahan dan masa tua. Dengan bertambahnya usia, paparan dengan alat kerja tangan pada waktu bekerja semakin lama pula, kemampuan elastisitas tulang, otot ataupun saraf semakin berkurang sehingga risiko CTS juga meningkat. ${ }^{4-8}$

Tabel 2. Gambaran Usia terhadap Kejadian CTS

\begin{tabular}{ccccc}
\hline Usia & \multicolumn{2}{c}{ CTS } & Total & $\begin{array}{c}\text { Persentase } \\
(\%)\end{array}$ \\
\cline { 2 - 3 } & Tidak & Ya & & \\
\hline $40-45$ thn & 27 & 10 & 37 & 37,0 \\
$46-50$ thn & 9 & 7 & 16 & 16,0 \\
$51-55$ thn & 15 & 9 & 24 & 24,0 \\
$56-60$ thn & 16 & 7 & 23 & 23,0 \\
\hline Total & 67 & 33 & 100 & 100 \\
\hline
\end{tabular}

Gambaran Lama Kerja terhadap Kejadian CTS

Berdasarkan tabel 3, didapatkan bahwa lama kerja responden mencuci pakaian dalam 1 hari antara $1 / 2$ jam -2 jam, responden dengan lama kerja $>1 \frac{1}{2}$ jam -2 jam tidak selalu mengalami CTS, sebaliknya responden yang meskipun hanya mencuci pakaian selama $1 / 2$ jam -1 jam tetap dapat mengalami CTS. Berdasarkan penelitian yang dilakukan oleh Bina Kurniawan dkk (2008), dimana lama kerja tidak ada hubungannya dengan CTS, hal ini tidak sesuai dengan teori yang mengatakan bahwa pekerjaan yang berisiko besar terancam CTS adalah pekerjaan yang banyak menggunakan anggota tubuh bagian tangan dan pergelangan tangan dan dalam jangka waktu panjang. Pada penelitian Bina dikatakan bahwa penyebab ketidaksesuaian tersebut antara lain adalah banyaknya waktu kerja yang digunakan untuk melakukan aktivitas kerja dengan gerakan tangan berulang. Responden yang memiliki lama 
kerja yang lebih lama belum tentu responden telah bekerja sekian lama tetapi dimungkinkan seorang pekerja banyak melakukan istirahat spontan di sela-sela waktu kerja. Istirahat spontan adalah istirahat pendek setelah pembebanan kerja. Pada saat bekerja, otot mengalami kontraksi atau kerutan dan saat istirahat terjadi pengendoran atau relaksasi otot. $^{6,7}$

Tabel 3. Gambaran Lama Kerja terhadap Kejadian CTS

\begin{tabular}{|c|c|c|c|c|}
\hline \multirow{2}{*}{$\begin{array}{l}\text { Lama } \\
\text { Kerja }\end{array}$} & \multicolumn{2}{|c|}{ CTS } & \multirow[t]{2}{*}{ Total } & \multirow{2}{*}{$\begin{array}{c}\text { Persentase } \\
(\%)\end{array}$} \\
\hline & Tidak & $\mathbf{Y a}$ & & \\
\hline $\begin{array}{c}1 / 2 \text { jam }-1 \\
\text { jam }\end{array}$ & 47 & 29 & 76 & 76,0 \\
\hline$>1$ jam -1 & 8 & 1 & 9 & 9,0 \\
\hline $\begin{array}{c}>1 \frac{1 / 2}{\mathrm{jam}}-2 \\
\text { jam }\end{array}$ & 12 & 3 & 15 & 15,0 \\
\hline Total & 67 & 33 & 100 & 100 \\
\hline
\end{tabular}

\section{Gambaran Obesitas terhadap Kejadian CTS}

Berdasarkan tabel 4, dari 33 orang yang menderita CTS, 20 orang mengalami obesitas (obesitas I dan II). Berdasarkan penelitian Ahmad Lazuardi (2016) dimana dari hasil penelitian tersebut responden yang mengalami obesitas (obesitas I dan II) memiliki hasil persentase paling tinggi yang terkena CTS dibandingkan nilai IMT yang lain. Berdasarkan teori yang dikemukakan oleh Bray, individu yang diklasifikasikan sebagai obesitas 2,5 kali lebih berisiko terdiagnosis CTS dibandingkan individu dengan IMT $<20$. Terdapat hubungan obesitas dan CTS yang diakibatkan oleh karena perlambatan konduksi nervus median di pergelangan tangan, hal ini berhubungan dengan jaringan lemak yang meningkat di dalam saluran karpal dan meningkatkan tekanan hidrostatik di seluruh saluran karpal pada individu obesitas dibandingkan individu dengan BB normal atau BB kurang. ${ }^{8,9}$

Tabel 4 Gambaran Obesitas terhadap Kejadian CTS

\begin{tabular}{ccccc}
\hline IMT & \multicolumn{2}{c}{ CTS } & Total & $\begin{array}{c}\text { Persentase } \\
(\%)\end{array}$ \\
\cline { 2 - 3 } & Tidak & Ya & & \\
\hline BB kurang & 1 & 5 & 6 & 6,0 \\
BB normal & 18 & 6 & 24 & 24,0 \\
Pra obesitas & 10 & 2 & 12 & 12,0 \\
Obesitas 1 & 24 & 12 & 36 & 36,0 \\
Obesitas 2 & 14 & 8 & 22 & 22,0 \\
\hline
\end{tabular}

$\begin{array}{lllll}\text { Total } & 67 & 33 & 100 & 100\end{array}$

\section{Gambaran Diabetes Melitus terhadap Kejadian CTS}

Berdasarkan tabel 5, didapatkan bahwa responden yang memiliki riwayat DM dan juga menderita CTS hanya 3 orang. Berdasarkan penelitian yang dilakukan oleh Dyah Wulaningsih (2015) didapatkan tidak adanya hubungan antara DM dengan CTS. Dikatakan bahwa perbedaan hasil penelitian disebabkan oleh perbedaan metode, yaitu kasus kontrol dan perbedaan jumlah sampel yang signifikan dan DM bukan merupakan faktor risiko independen dari CTS. Selain itu penelitian di Institusi Rumah Sakit di Semarang (2006) terdapat 34 pasien baru terdiagnosa CTS atau sekitar 4\% dari 838 pasien baru, dimana penderita yang terdiagnosis CTS dan juga memiliki riwayat diabetes melitus yaitu 5 orang atau sekitar $14,7 \%$. Persentase penderita DM yang juga terkena CTS memang sedikit. Mekanisme terjadinya CTS pada pasien DM terkait dengan mekanisme neuropati. Saat hiperglikemi tidak terkontrol terjadi glikosilasi yang menyebabkan kekakuan dan penebalan protein tendon dari terowongan karpal. ${ }^{10-12}$

\section{Tabel 5 Gambaran Riwayat Diabetes Melitus terhadap Kejadian CTS}

\begin{tabular}{ccccc}
\hline \multirow{2}{*}{$\begin{array}{c}\text { Diabetes } \\
\text { Melitus }\end{array}$} & \multicolumn{2}{c}{ CTS } & Total & $\begin{array}{c}\text { Persentase } \\
(\mathbf{\%})\end{array}$ \\
\cline { 2 - 3 } & Tidak & Ya & & \\
\hline Tidak DM & 60 & 30 & 90 & 90,0 \\
DM & 7 & 3 & 10 & 10,0 \\
\hline Total & 67 & 33 & 100 & 100 \\
\hline
\end{tabular}

\section{Gambaran Usia Kehamilan terhadap Kejadian CTS}

Berdasarkan tabel 6, pada usia kehamilan 12 minggu - 20 minggu 2 orang menderita CTS, usia kehamilan 21 minggu 30 minggu 4 orang menderita CTS, usia kehamilan $>30$ minggu 1 orang menderita CTS dan sebanyak 91 orang tidak ingat apakah pernah mengalami gejala CTS yang semakin berat pada saat hamil, dari 91 orang 26 orang menderita CTS sedangkan 65 orang tidak menderita CTS. Berdasarkan penelitian oleh Sigi Purwanto dan Bina Melvia (2015), didapatkan kejadian CTS mayoritas dijumpai 
pada usia kehamilan 13-28 minggu (trimester kedua). Sedangkan, menurut Meems (2015), menyatakan bahwa kejadian CTS secara signifikan meningkat pada usia kehamilan 32 minggu (trimester 3). Selama kehamilan, perubahan hormonal menyebabkan a) retensi cairan yang dapat mempersempit terowongan karpal dan menekan saraf medianus; b) hormon juga melunakkan ligamen yang membentuk atap terowongan karpal dan c) peningkatan berat badan ibu. Perbedaan hasil dapat terjadi seperti pada penelitian yang dilakukan pada 100 orang wanita hamil di rumah sakit Al-Zahra di Dubai didapatkan bahwa sekitar $42 \%$ asimtomatik pada saat hamil. Oleh karena itu, pada wanita hamil dapat direkomendasikan untuk melakukan tes elektrodiagnostik pada awal kehamilan untuk mendiagnosis kasus asimtomatik. Mengingat studi yang menggunakan elektrodiagnosis, hasilnya menunjukkan prevalensi CTS yang tinggi pada kehamilan, namun pada mereka yang hanya menggunakan tes klinis, prevalensinya rendah. Perbedaan ini menunjukkan ketidaktepatan tes klinis dalam mendiagnosis kasus subklinis CTS pada wanita hamil. Oleh karena itu, dengan menggunakan kriteria elektrodiagnostik dapat digunakan untuk skrining. Dalam penelitian tersebut, sensitivitas dan spesifisitas tes klinis rendah dibandingkan dengan elektrodiagnosis. Jadi, skrining pasien yang hanya menggunakan kriteria klinis meningkatkan kemungkinan kesalahan. ${ }^{13-15}$

Tabel 6 Gambaran Usia Kehamilan terhadap Kejadian CTS

\begin{tabular}{ccccc}
\hline Usia & \multicolumn{2}{c}{ CTS } & Total & $\begin{array}{c}\text { Persentase } \\
\text { Kehamilan }\end{array}$ \\
\cline { 2 - 3 } & Tidak & Ya & & \\
\hline Tidak ingat & 65 & 26 & 91 & 91,0 \\
$\leq 12$ minggu & 0 & 0 & 0 & 0 \\
$12-20$ minggu & 0 & 2 & 2 & 2,0 \\
$21-30$ minggu & 1 & 4 & 5 & 5,0 \\
$>30$ minggu & 1 & 1 & 2 & 2,0 \\
\hline Total & 67 & 33 & 100 & 100 \\
\hline
\end{tabular}

\section{Gambaran Posisi Pergelangan Tangan terhadap Kejadian CTS}

Berdasarkan hasil tabel 7 didapatkan bahwa semua responden mencuci pakaian dengan posisi tangan yang janggal yaitu sebanyak 100 orang $(100 \%)$, dari 100 orang 67 orang $(67,0 \%)$ tidak menderita CTS dan 33 orang $(33,0 \%)$ menderita CTS. Berdasarkan penelitian oleh Fatmawaty dan Andi (2015), mengatakan bahwa beberapa hasil penelitian menuliskan responden yang melakukan pekerjaan dengan postur janggal tidak berisiko mengalami CTS dan dalam beberapa kondisi, justru pekerja yang tidak melakukan pekerjaan dengan postur janggal justru memiliki risiko CTS. Hal ini dapat terjadi karena dipengaruhi faktor pekerjaan fisik lain seperti gerakan berulang dan pekerjaan menggenggam. Berdasarkan teori, posisi normal atau netral pada tangan dan pergelangan tangan dalam melakukan proses kerja adalah dengan posisi sumbu lengan terletak satu garis lurus dengan jari tengah. Apabila sumbu tangan tidak lurus tetapi mengarah ke berbagai posisi, maka dapat dikatakan posisi tersebut janggal atau tidak netral. Mekanisme terjadinya CTS adalah terjadinya penegangan dan penekanan pada saraf median di pergelangan tangan, ketika pergelangan tangan berada dalam posisi ekstrim. $^{7,16}$

Tabel 7 Gambaran Posisi Pergelangan Tangan terhadap Kejadian CTS

\begin{tabular}{|c|c|c|c|c|}
\hline \multirow{2}{*}{$\begin{array}{c}\text { Posisi } \\
\text { Pergelangan } \\
\text { tangan }\end{array}$} & \multicolumn{2}{|c|}{ CTS } & \multirow[t]{2}{*}{ Total } & \multirow{2}{*}{$\begin{array}{c}\text { Persen } \\
\text { tase } \\
(\%)\end{array}$} \\
\hline & Tidak & Ya & & \\
\hline Janggal & 67 & 33 & 100 & 100 \\
\hline Tidak janggal & 0 & 0 & 0 & 0 \\
\hline Total & 67 & 33 & 100 & 100 \\
\hline
\end{tabular}

\section{Simpulan}

Berdasarkan hasil penelitian yang telah dilakukan, diperoleh beberapa kesimpulan sebagai berikut :

1. Kejadian CTS pada Ibu rumah tangga yang mencuci pakaian menggunakan tangan di Desa Guji Baru yaitu 33\%.

2. Kelompok usia dengan persentase tertinggi yang mengalami CTS adalah usia 40-45 tahun yaitu 10 orang $(30 \%)$

3. Lama kerja dengan persentase penderita CTS tertinggi adalah $1 / 2-1$ jam yaitu 29 orang $(88 \%)$

4. Obesitas ditemukan pada 20 orang (60\%) penderita CTS 
5. Diabetes ditemukan pada 3 orang (9\%) penderita CTS

6. CTS ditemukan pada saat hamil oleh 7 orang $(21 \%)$

7. Semua responden mencuci pakaian dengan posisi janggal $(100 \%)$

\section{Daftar Pustaka}

1. Djatmiko RD. Keselamatan dan kesehatan kerja. Yogyakarta: Deepublish; 2016: 76

2. Salawati L, Syahrul. Carpal tunnel syndrome. Aceh: Jurnal Kedokteran Syah Kuala. 2014;14(1): 29-33

3. Rambe AS. Sindroma terowongan karpal (carpal tunnel syndrome). 2004. Diunduh dari

URL:.http://repository.usu.ac.id/bitstream /123456789/3459/1 penysaraf-aidil2.pdf.

Diakses pada tanggal 22 April 2017

4. Aroori S, Spence RAJ. Carpal tunnel syndrome. NCBI: Ulster med J. 2008;77(1): 6-17

5. Kurniawan B, Jayanti S, Setyaningsih Y. Faktor risiko kejadian carpal tunnel syndrome (CTS) pada wanita pemetik melati di desa Karangcengis, Purbalingga. Jurnal promosi kesehatan Indonesia. 2008;3(1): 35

6. Lazuardi AI. Determinan gejala carpal tunnel syndrome pada pekerja pemecah batu di Kecamatan Sumbersari dan Sukowono Kabupaten Jember. Jember: Fakultas kesehatan masyarakat Universitas Jember; 2016; 4-5

7. Fitriani RN. Faktor-faktor yang berhubungan dengan dugaan carpal tunnel syndrome (CTS) pada operator komputer bagian sekretariat di Inspektorat Jendral Kementrian Pekerjaan Umum. Jakarta: Universitas Islam Negeri Syarif Hidayatulla.2012

8. Ilyas MF. Hubungan usia dan masa kerja dengan posisi pergelangan tangan terhadap carpal tunnel syndrome pada supir bajaj di Jakarta Barat. Skripsi. Jakarta: Universitas Muhammadiyah Jakarta; 2015

9. Werner RA, Albers JW, Franzblau A, Armstrong TJ. The relationship between body mass index and the diagnosis of carpal tunnel syndrome. New York: John wiley sons Inc. 2000;17: 635-6

10. Tamba LMT, Pudjowidyanto $\mathrm{H}$. Karakteristik penderita sindroma terowongan karpal (STK) di poliklinik instalasi rehabilitasi medik RS Dr. Kariadi Semarang 2006. Media Medika Indonesia. 2009;43(16): 10-3

11. Sibarani M.H.R. Gangguan muskuloskeletal pada diabetes melitus. Batam: Poliklinik Bid Dokkes Kepri. 2015;42(8)

12. Wulaningsih D., Pinzon Rizaldy T., Pramudita Esdras A. Hubungan diabetes melitus terhadap kejadian sindroma terowongan karpal di RS Bethseda Yogyakarta. Yogyakarta: berkala ilmu kedokteran duta wacana. 2015;1(1): 68

13. Meems M. Carpal tunnel syndrome during pregnancy and the postpartum period and the effect of mechanical traction treatment. Tilburg Unversity: Medisch centrum; 2016

14. Purwanto S., Girsang BM. Identifikasi karakteristik dan prevalensi carpal tunnel syndrome pada ibu hamil. Palembang : Program Studi Ilmu Fakultas Kedokteran Universitas Sriwijaya; 2015: 142-3

15. Khosrawi S., Maghrouri R. The prevalence and severity of carpal tunnel syndrome during pregnancy. US national library of medicine national institutes of health : NCBI. 2012; 1(43)

16. Mallapiangi F, Wahyudi AA. Gambaran faktor pekerjaan dengan kejadian carpal tunnel syndrome (CTS) pada pengrajin batu tatakan di desa Lempang Kec. Tanete Riaja Kabupaten Barru. Makassar: Al-Sihah-Public Health Science Journal. 2015;6(2): 24 